\title{
Serum IL-33 as a biomarker in different diseases: useful parameter or much need for clarification?
}

\author{
Stefan Erfurt ${ }^{1}$, Meike Hoffmeister ${ }^{2}$, Stefanie Oess ${ }^{2}$, Katharina Asmus ${ }^{1}$, Oliver Ritter ${ }^{1}$, Susann Patschan ${ }^{1}$, Daniel Patschan ${ }^{1}$ \\ ${ }^{1}$ Department of Medicine 1, University Hospital Brandenburg, Medical School (MHB) Theodor Fontane, Brandenburg - Germany \\ ${ }^{2}$ Institute of Biochemistry, Brandenburg Medical School (MHB) Theodor Fontane, Brandenburg - Germany
}

\begin{abstract}
Interleukin-33 (IL-33), a member of the IL-1 family, is critically involved in the modulation of the activity of a diverse range of immunocompetent cells. Essential roles have been implicated in cardioprotection, in both innate and adaptive immune responses in mucosal organs, and in the maintenance of adipose tissue cells. Over the past 10 years, several studies evaluated the usability of IL-33 as a biomarker in diseases of inflammatory and noninflammatory origin. Our group is currently evaluating the predictive role of serum IL-33 in acute kidney injury (AKI). The aim of the article is to discuss selected studies on IL-33 in different diseases and its potential role as a biomarker molecule.
\end{abstract}

Keywords: Biomarker, IL-33, Inflammatory diseases, Noninflammatory diseases

\section{Introduction}

The identification of biomarkers for either early diagnosis or risk prediction in various diseases remains a fundamental goal in the whole field of medicine. A sophisticated discussion of all or of at least the most important findings in recent years is impossible in one single article that is intended to focus on one potential marker molecule. The literature on biomarkers in even one particular disease, such as acute kidney injury (AKI), is vast. For illustrative purposes, it needs to be mentioned that more than 100 candidate molecules have been investigated in AKI subjects over the past 20 years (1). Only few parameters (e.g., NGAL, KIM-1 (2,3)) or combinations of two proteins such as the product of urinary insulin-like growth factor-binding protein (IGFBP-7) and tissue inhibitor of metalloproteinase (TIMP-2) $(4,5)$ have been proven as reliable tools for diagnostic/prognostic purposes under certain AKI-associated conditions. However, no parameter can truly replace serum creatinine for measuring excretory kidney function in daily clinical practice, despite creatinine far from being an "optimal" biomarker. In 2019, our group

Received: August 3, 2021

Accepted: November 10, 2021

Published online: November 30, 2021

Corresponding author:

Daniel Patschan

Zentrum Innere Medizin 1

Universitätsklinikum Brandenburg

Medizinische Hochschule Brandenburg

Hochstraße 29

14770 Brandenburg - Germany

daniel.patschan@mhb-fontane.de published a study on cytokine profiling in patients with ANCAassociated vasculitis (AAV) (6). Serum from healthy subjects and from patients with AAV or other autoimmune-mediated diseases was analyzed for concentrations of certain pro- and anti-inflammatory mediators. It became apparent that serum IL-33 was significantly higher in AAV subjects than in controls. Also, AAV patients with necrotizing glomerulonephritis (NGN) differed from AAV subjects without NGN. These findings led to the hypothesis of IL-33 as a potential biomarker in acute renal diseases, namely in AKI. The respective study has been initiated and is ongoing. The current article will summarize the most important references on IL-33 as a diagnostic tool and risk predictor in genetic and acquired diseases.

\section{Interleukin-33-origin and physiology}

Interleukin-33 (IL-33) belongs to the IL-1 family of cytokines (7). Common feature of the latter is a beta-trefoil structure, which has been identified in proteins such as IL-1alpha and -beta, IL-1Ra, and IL-18. IL-33 was initially found within endothelial cell nuclei of so-called human high endothelial venules (HEV). Baekkevold et al (8) described the protein as NF (nuclear factor)-HEV. Later, Pichery and colleagues (9) detected IL-33 within the nuclei of murine cells in various tissues, such as epithelial cells, lymphoid organs, brain, and embryonic tissue. Herein, the cytokine was expressed in a constitutive manner. In contrast, blood vessels did not show constitutive IL-33 expression. Within nuclei, IL-33 binds to chromatin (10); in the extracellular space however, it interacts with ST2. The latter exists as membrane-bound and soluble isoform (sST2), respectively (11). Interleukin-33 mediates so-called alarmin function. Alarmins, which are represented by extracellularly secreted proteins of various 
origin and phenotype, indicate cell/tissue damage. Subsequently, immune cells are activated. In this context, IL-33 has been shown to modulate the activity of mast cells, group 2 innate lymphoid cells (ILC2s), T helper 2 cells, eosinophils, basophils, dendritic cells, macrophages, and others (12). Essential roles of the cytokine have been implicated in cardioprotection (11), in both innate and adaptive immune responses in mucosal organs (13) and in the maintenance of adipose tissue cells (via immune cell modulation) (14).

\section{Quantification of serum IL-33}

The data on IL-33 quantification by either ELISA (enzymelinked immunosorbent assay) or multiplex technologies are heterogeneous. By far not all groups initially succeeded in measuring serum levels of the cytokine. Firstly, Krychtiuk and colleagues (15), who identified low serum IL-33 to be predictive in intensive care-treated patients, did not detect the protein in 57 out of 223 subjects. In 2016, Ketelaar et al (16) reported the results of serum IL-33 quantification by using four different ELISA kits (Quantikine and DuoSet, R\&D systems, respectively; ADI-900-201, Enzo Life Sciences; SKR038, GenWay Biotech Inc, San Diego, USA). Serum samples were drawn from asthma patients. The authors included different numbers of samples per individual kit: Quantikine$n=45$; DuoSet $-n=17$; ADI-900-201-n = 17; SKR038-n = 22). Surprisingly, the percentages of samples above the lower detection limit (LLD) were 0 (zero) in two kits (ADI-900-201 and SKR038). The Quantikine kit showed only 2\% of all samples above the LLD, the DuoSet kit was successful in at least $76 \%$. Comparable findings were reported by Asaka et al (17), who also employed the Quantikine kit. Difficulties in IL-33 quantification were also reported by Rivière and colleagues (18). In this context, it needs to be noted that erythrocytes contain IL-33 in relevant concentrations. Thus, hemolysis may increase serum IL-33 concentrations and potentially adulterate the findings in biomarker-related studies (19).

\section{Aberrant IL-33 in diseases: elevation}

\section{Genetic disorders}

Behairy and colleagues (20) evaluated 60 infants with cholestasis, assigned to one of two subgroups with versus without biliary atresia (BA and non-BA group). Subjects belonging to the first group showed significantly higher serum IL-33. Also, IL-33 was higher in both groups as compared to healthy controls. Finally, IL-33 correlated with aspartate and alanine aminotransferase (ALT), and with serum bilirubin in a positive manner, respectively. Since cytokine levels additionally correlated with the fibrosis stage, the authors concluded a potential (pathogenic) role of IL-33 in BA disease progression.

\section{Cardiovascular diseases}

A study in subjects with chronic kidney disease (CKD) was published in 2017 (21). Two-hundred and thirty-eight CKD patients were followed up for 24 months. Both serum
IL-33 and ST2, the circulating isoform of the IL-33 receptor, were quantified and associated with cardiovascular events and parameters of endothelial dysfunction (flow-mediated vasodilation, FMD). The two analytes increased with decreasing estimated glomerular filtration rate and elevated levels were associated with impaired FMD and cardiovascular risk. Nevertheless, Bao et al (22) failed to show increased IL-33 in CKD subjects. In experimental studies TGF- $\beta$ KO (knock out) enhanced IL-33, and while its inflammatory regulation varies with the disease, in the heart it protects against pathological remodeling after infarction, myocyte hypoxia, pressure overload, and increased $\mathrm{Ca}^{2+}$ release from the SR (sarcoplasmic reticulum) which is tunneled to mitochondria via mitochondrial RyR, leading to stimulation of mitochondrial adenosine triphosphate production (23).

\section{Autoimmune-mediated diseases}

In 2010, Mu et al published data on rheumatoid arthritis (RA) (24). Three groups were evaluated: healthy controls, RA subjects, and patients with osteoarthritis. The cytokine was not detectable in controls and osteoarthritis but in almost 100 RA subjects (42.2\%). Cytokine concentrations correlated with the RF and anti-CCP titers, respectively, and anti-TNFalpha therapy reduced IL-33 serum levels. IL-33 elevation in RA was also shown by Hong and colleagues (25). Borsky et al (26) performed a study in psoriasis vulgaris subjects, intended to quantify serum levels of alarmins. The latter act as danger signals. The following factors were analyzed: HMGB1, IL-33, S100A7, and S100A12. In total, 63 psoriasis patients and 95 controls were included. All four proteins were elevated in a significant manner. Correlations between serum concentrations and disease activity were however not identified. Our group studied subjects with AAV and with other autoimmune-mediated diseases (6). Serum concentrations of the following parameters were measured: IL-1 $\beta$, IL-6, IL-17 A, IL-17 F, IL-21, IL-22, IL-23, TNF- $\alpha$, sCD40L, IL-4, IL-10, IL-25, IL-31, IL-33, and INF- $\gamma$. A total number of 62 AAV subjects were included in the study (39 females; 23 males). Forty-five subjects were PR3+, 17 subjects showed ANCA specificity for MPO (myeloperoxidase). Serum IL-33 was elevated in AAV and SSc (systemic sclerosis). In AAV, higher levels were found in non-NGN. Minaga et al (27) investigated a rarer type of disease, type 1 autoimmune pancreatitis (type 1 AIP), belonging to the heterogeneous group of IgG4-related disease (IgG4-RD). The study revealed higher levels of interferonalpha and of IL-33 in type 1 AIP subjects in comparison to individuals with chronic pancreatitis of other origin and to healthy controls. Bakr et al (28) analyzed serum IL-33 in patients with pemphigus vulgaris. Affected subjects showed higher cytokine levels than healthy controls. Also, serum levels significantly correlated with the activity of the disease (measured by the Pemphigus Disease Area Index, PDAI).

\section{Neoplasia}

A study in patients with newly diagnosed prostate cancer was published in 2019 (29). One-hundred and fifty individuals were included. Serum IL-33 was higher than in controls, 
particularly in subjects with higher disease stages. Nevertheless, cytokine concentrations did not differ between certain predefined genotypes. As a matter of fact, elevated IL-33 has also been documented in other malignant diseases such as gastric cancer (30), endometrial cancer (31), non-small cell lung cancer (32), and breast cancer (33).

\section{Sepsis}

Sepsis may be regarded as an archetype of a widespread inflammatory disease. In 2016, Çekmez and colleagues (34) reported data from 128 septic children (20 of these were controls). Finally, 68 individuals were excluded since blood cultures were negative. Serum IL-33 differed significantly between the two groups of controls vs sepsis $(1.1 \pm 0.28 \mathrm{ng} /$ $\mathrm{mL}$ vs $5.23 \pm 1.80 \mathrm{ng} / \mathrm{mL} ; \mathrm{p}=0.01$ ). Two years later, another study performed in septic children (neonates) (35) showed comparable findings with a rapid IL-33 increase at the first day after diagnosis, followed by a decrease over time (days 3 and 7).

\section{Others}

Although immune-mediated mechanisms are substantially involved in the pathogenesis of asthma bronchiale, the disorder has been placed in this section. Bahrami and colleagues (36) included 61 affected children and 63 healthy controls in their analyses and found serum IL-33 to be significantly elevated. Blood cytokine levels increased with increasing disease severity. The predictive value of serum IL-33 in polytraumatized subjects was analyzed by Halát and colleagues (37). The specific aim was to evaluate whether IL-33 is suitable for the prediction of pulmonary complications. The study included 130 patients, serum samples were obtained at the time of hospital admission and 2 days later. Subjects that developed both parenchymal lung injury and subsequent Acute Respiratory Distress Syndrome (ARDS) showed particularly high serum IL-33 at the time of admission. It was hypothesized that the cytokine is involved in promoting sustained lung injury in traumatized patients. Sundnes et al (38) also published a trial in traumatized individuals $(n=136)$. Plasma samples were collected at the time of hospital admission and several hours later $(2,4,6$, and 8 hours). The analyses showed a rapid and transient IL-33 increase in a subset of patients. The latter presented with more intense tissue injuries and a higher degree of coagulopathy. Another study related to serum patterns of alarmins (Danger-Associated Molecular Patterns-DAMPs) focused on schizophrenia. The following molecules were quantified: IL-33, SST2, HMGB1, and S100B (39). The study included 68 patients suffering from chronic schizophrenia and 29 healthy controls. All four analytes were higher in the disease group. It was concluded that alarmins may be involved in latent neuroinflammation underlying/perpetuating schizophrenia. Yuan and colleagues focused on chronic hepatitis $B(\mathrm{CHB})(40)$. A total number of $130 \mathrm{CHB}$ patients were included, 48 cases were defined as stable, 50 patients showed progression to acute-on-chronic liver failure (ACLF), 30 individuals also progressed but with overall milder dynamics (pre-ACLF). The highest IL-33 levels were detected in ACLF patients, associations were found with serum ALT, aspartate transaminase, and the Model EndStage Liver Disease (MELD) score, respectively. The combination of serum IL-33 and the MELD score was predictive with regard to the 90 -days mortality. Thus, IL-33 was proposed as prognostic marker in CHB-associated liver disease. In 2021, Venkataraman et al (41) published multiplex immune assay data from children with "Paediatric inflammatory multisystem syndrome temporally associated with SARSCoV-2 infection (PIMS-TS)." Numerous cytokines were elevated, including IL-33. Duan and colleagues analyzed gout patients and found increased IL-33 in respective subjects with even higher levels in those individuals without impaired kidney function (42). Also, IL-33 was negatively correlated with markers of kidney dysfunction.

\section{Aberrant IL-33 in diseases: suppression}

\section{Cardiovascular diseases}

Experimental data showed neuroprotective effects of IL-33 $(43,44)$. Therefore, Chen et al $(45)$ evaluated the relationship between serum IL-33 and the risk for hemorrhage transformation (HT) of acute ischemic stroke (AIS) in humans. More than 150 individuals were included, none of these received thrombolytic therapy. Patients were assigned to the HT group if any radiographic signs of HT became apparent during the first 2 weeks after AIS diagnosis. Multivariate regression analysis identified IL-33 as an independent HT predictor (lower serum IL-33 levels were associated with higher HT risk). The authors expanded their analyses in the context of poststroke depression (46) and found a comparable (inverse) association between serum IL-33 and the risk for depression after AIS. Together, the data confirmed the concept of IL-33-mediated neuroprotection, even in humans. In this context, an important study by Li et al (47) evaluated long-term outcome variables of stroke patients in relation to initial serum IL-33. Higher cytokine levels were associated with a better 2-year outcome of affected individuals. Low serum IL-33 was finally also shown to be predictive in patients with intracerebral hemorrhage (48). A study in patients with heart failure with reduced ejection fraction (HF-REF) was published by Segiet et al (49). One hundred and fifty-five HF-REF individuals (males: 106, females: 49) were included, the mean left ventricular ejection fraction was $32.13 \pm 12.8 \%$. Patients displayed lower mean serum IL-33 as compared to controls. Also, cytokine levels were lower in HF-REF of ischemic origin as opposed to HF-REF of other etiology.

\section{Autoimmune-mediated diseases}

A rarer autoimmune-mediated disorder (at least in central Europe), Behçet's disease was evaluated by Koca et al (50) who included 117 affected individuals. While patients' serum IL-33 did not differ from control levels, active disease states were associated with lower IL-33. Nevertheless, certain allelic variations did not differ in serum IL-33. 


\section{Others}

In contrast to the study by Halát et al (37), who found IL-33 to be elevated in polytraumatized patients, another investigation performed in critically ill subjects showed opposite findings. Krychtiuk and colleagues (15) evaluated the predictive value of both IL-33 and SST2 with regard to the 30 days mortality in 223 intensive care patients. IL-33 was not detectable at all in 57 subjects. Serum IL-33 concentrations below the median strongly predicted death in an independent manner. Lower-than-normal IL-33 concentrations were also documented in osteoporosis (51) and in amyotrophic lateral sclerosis (52). Finally, Hasan et al (53) showed a negative correlation between IL-33 and the body mass index. They also found IL-33 to negatively correlate with $\mathrm{HbA} 1 \mathrm{C}$ in nondiabetic individuals.

\section{No aberrant IL-33 in diseases}

\section{Cardiovascular diseases}

Firouzabadi and colleagues (54) measured serum IL-33 and the soluble isoform of its receptor (sST2) in 44 heart failure patients ( $n=25$ under carvedilol treatment vs $n=19$ without beta-blocker therapy) and in 22 healthy controls. The analyses did not reveal any differences between any of the three groups, which led to the conclusion that cardioprotective effects of carvedilol are most likely not mediated via the IL-33/sSTs axis. Two other studies related to acute cardiovascular diseases did also not show any differences in serum IL-33 between controls and patients. Demyanets et al (55) investigated subjects with stable angina, NSTEMI (nonST-segment elevation myocardial infarction), or STEMI in comparison to healthy controls. Dhillon and colleagues (56) analyzed NSTEMI subjects.

Table I summarizes studies on serum IL-33 in diseases, assigned to one out of three groups: elevation/suppression or constant IL-33.

\section{Conclusions}

The data on serum IL-33 in human diseases are heterogeneous. On the one hand, methodological difficulties in measuring serum IL-33 may occur and must always be put into consideration if low levels or no protein at all is detectable. The majority of studies in which IL-33 quantification

TABLE I - Studies in serum IL-33 in inflammatory and noninflammatory disorders

\begin{tabular}{|c|c|c|}
\hline IL-33 elevation & IL-33 suppression & Constant IL-33 \\
\hline Biliary atresia (20) & HT of AIS (45) & Heart failure (54) \\
\hline CKD (21) & Poststroke depression (46) & CKD (22) \\
\hline Rheumatoid arthritis (24) & Long-term outcome after stroke (47) & Stable angina pectoris, NSTEMI, STEMI (55) \\
\hline Rheumatoid arthritis (25) & Intracerebral hemorrhage (48) & NSTEMI (56) \\
\hline Psoriasis vulgaris (26) & HF-REF (49) & \\
\hline Prostate cancer (29) & Behçet's disease (50) & \\
\hline Gastric cancer (30) & Critically ill subjects (15) & \\
\hline Endometrial cancer (31) & Osteoporosis (51) & \\
\hline Non-small cell lung cancer (32) & Amyotrophic lateral sclerosis (52) & \\
\hline Breast cancer (33) & Increased body weight (53) & \\
\hline \multicolumn{3}{|l|}{ Sepsis in infants (34) } \\
\hline \multicolumn{3}{|l|}{ Sepsis in infants (35) } \\
\hline \multicolumn{3}{|l|}{ Asthma bronchiale in children (36) } \\
\hline \multicolumn{3}{|l|}{ Polytrauma (37) } \\
\hline \multicolumn{3}{|l|}{ Trauma (38) } \\
\hline \multicolumn{3}{|l|}{ ANCA-associated vasculitis (6) } \\
\hline \multicolumn{3}{|l|}{ Pemphigus vulgaris (28) } \\
\hline \multicolumn{3}{|l|}{ Type 1 autoimmune pancreatitis (27) } \\
\hline \multicolumn{3}{|l|}{ Schizophrenia (39) } \\
\hline \multicolumn{3}{|l|}{$\begin{array}{l}\text { Hepatitis B-associated acute-on-chronic } \\
\text { liver failure }(40)\end{array}$} \\
\hline \multicolumn{3}{|l|}{ PIMS-TS (41) } \\
\hline gout (42) & & \\
\hline
\end{tabular}


succeeded showed higher blood concentrations of the cytokine. However, to identify a pattern that potentially allowed conclusions on the exact role of serum IL-33 in inflammatory and noninflammatory diseases is quite difficult. We cited a total number of 21 studies that reported IL-33 elevation under pathological circumstances. Thirteen out of these 21 investigations evaluated diseases with distinct inflammatory pathogenesis (exceptions: CKD, BA, schizophrenia, five malignancies). Two out of 10 studies reporting lower IL-33 were nevertheless also performed in inflammatory disease states (Behçet's disease, critically ill subjects). Thus, it may be concluded that elevation of serum IL-33 should be expected with higher probability in inflammatory than in noninflammatory disorders. The references on malignancies with elevated IL-33 were all referring to carcinomas. Activation of the immune system is known to significantly occur in malignant disorders. It is therefore not surprising that diseases such as heart failure with preserved or reduced ejection fraction, ischemic stroke, or even most cases of AKI are not associated with increased serum IL-33. Regarding the heterogeneity of diseases with either IL-33 elevation or suppression, it is hardly possible to propose the molecule as specific biomarker at the moment.

\section{Disclosures}

Conflict of interest: The authors declare no conflict of interest. Financial support: This research received no specific grant from any funding agency in the public, commercial, or not-for-profit sectors. Authors' contributions: SE searched for literature and corrected the article. He also performed experiments related to IL-33. MH corrected the article and is involved in a project related to IL-33. SO provided additional references and helped in structuring the article. KA assisted in writing. OR assisted in writing. SP corrected the article and designed the table. DP initiated writing, finalized the current version, and is also involved in a project related to IL-33.

\section{References}

1. Schrezenmeier EV, Barasch J, Budde K, Westhoff T, Schmidt-Ott $\mathrm{KM}$. Biomarkers in acute kidney injury-pathophysiological basis and clinical performance. Acta Physiologica (Oxford, England). 2016.

2. Huo W, Zhang K, Nie Z, Li Q, Jin F. Kidney injury molecule-1 (KIM-1): a novel kidney-specific injury molecule playing potential double-edged functions in kidney injury. Transplant Rev (Orlando). 2010;24(3):143-146. CrossRef PubMed

3. Shang W, Wang Z. The update of NGAL in acute kidney injury. Curr Protein Pept Sci. 2017;18(12):1211-1217. CrossRef PubMed

4. Fan W, Ankawi G, Zhang J, et al. Current understanding and future directions in the application of TIMP-2 and IGFBP7 in AKI clinical practice. Clin Chem Lab Med. 2019;57(5):567-576. CrossRef PubMed

5. Nalesso F, Cattarin L, Gobbi L, Fragasso A, Garzotto F, Calò LA. Evaluating Nephrocheck ${ }^{\circ}$ as a predictive tool for acute kidney injury. Int J Nephrol Renovasc Dis. 2020;13:85-96. CrossRef PubMed

6. Hoffmann JC, Patschan D, Dihazi $\mathrm{H}$, et al. Cytokine profiling in anti neutrophil cytoplasmic antibody-associated vasculitis: a cross-sectional cohort study. Rheumatol Int. 2019;39(11): 1907-1917. CrossRef PubMed
7. Fields JK, Günther S, Sundberg EJ. Structural basis of IL-1 family cytokine signaling. Front Immunol. 2019;10:1412. CrossRef PubMed

8. Baekkevold ES, Roussigné M, Yamanaka T, et al. Molecular characterization of NF-HEV, a nuclear factor preferentially expressed in human high endothelial venules. Am J Pathol. 2003;163(1):69-79. CrossRef PubMed

9. Pichery M, Mirey E, Mercier P, et al. Endogenous IL-33 is highly expressed in mouse epithelial barrier tissues, lymphoid organs, brain, embryos, and inflamed tissues: in situ analysis using a novel II-33-LacZ gene trap reporter strain. J Immunol. 2012;188(7):3488-95.

10. Roussel L, Erard M, Cayrol C, Girard JP. Molecular mimicry between IL-33 and KSHV for attachment to chromatin through the H2A-H2B acidic pocket. EMBO Rep. 2008;9(10):1006-1012. CrossRef PubMed

11. Kotsiou OS, Gourgoulianis KI, Zarogiannis SG. IL-33/ST2 axis in organ fibrosis. Front Immunol. 2018;9:2432. CrossRef PubMed

12. Cayrol C, Girard JP. Interleukin-33 (IL-33): a nuclear cytokine from the IL-1 family. Immunol Rev. 2018;281(1):154-168. CrossRef PubMed

13. Drake LY, Kita H. IL-33: biological properties, functions, and roles in airway disease. Immunol Rev. 2017;278(1):173-184. CrossRef PubMed

14. de Oliveira MFA, Talvani A, Rocha-Vieira E. IL-33 in obesity: where do we go from here? Inflamm Res. 2019;68(3):185-194. CrossRef PubMed

15. Krychtiuk KA, Stojkovic S, Lenz M, et al. Predictive value of low interleukin-33 in critically ill patients. Cytokine. 2018;103: 109-113. CrossRef PubMed

16. Ketelaar ME, Nawijn MC, Shaw DE, Koppelman GH, Sayers I. The challenge of measuring IL-33 in serum using commercial ELISA: lessons from asthma. Clin Exp Allergy. 2016;46(6): 884-887. CrossRef PubMed

17. Asaka D, Yoshikawa M, Nakayama T, Yoshimura T, Moriyama $\mathrm{H}$, Otori N. Elevated levels of interleukin-33 in the nasal secretions of patients with allergic rhinitis. Int Arch Allergy Immunol. 2012;158(s1)(suppl 1):47-50. CrossRef PubMed

18. Rivière $E, L y B$, Boudaoud $S$, et al. Pitfalls for detecting interleukin-33 by ELISA in the serum of patients with primary Sjögren syndrome: comparison of different kits. Ann Rheum Dis. 2016;75(3):633-635. CrossRef PubMed

19. Wei J, Zhao J, Schrott V, et al. Red blood cells store and release interleukin-33. J Investig Med. 2015;63(6):806-810. CrossRef PubMed

20. Behairy OG, Elsadek AE, Behiry EG, Elhenawy IA, Shalan $\mathrm{NH}_{\text {, }}$ Sayied KR. Clinical value of serum interleukin-33 biomarker in infants with neonatal cholestasis. J Pediatr Gastroenterol Nutr. 2020;70(3):344-349. CrossRef PubMed

21. Gungor O, Unal HU, Guclu A, et al. IL-33 and ST2 levels in chronic kidney disease: associations with inflammation, vascular abnormalities, cardiovascular events, and survival. PLoS One. 2017;12(6):e0178939. CrossRef PubMed

22. Bao YS, Na SP, Zhang P, et al. Characterization of interleukin-33 and soluble ST2 in serum and their association with disease severity in patients with chronic kidney disease. J Clin Immunol. 2012;32(3):587-594. CrossRef PubMed

23. Seidlmayer LK, Kuhn J, Berbner A, et al. Inositol 1,4,5-trisphosphate-mediated sarcoplasmic reticulum-mitochondrial crosstalk influences adenosine triphosphate production via mitochondrial $\mathrm{Ca} 2+$ uptake through the mitochondrial ryanodine receptor in cardiac myocytes. Cardiovasc Res. 2016;112(1): 491-501. CrossRef PubMed

24. Mu R, Huang HQ, Li YH, Li C, Ye H, Li ZG. Elevated serum interleukin 33 is associated with autoantibody production in 
patients with rheumatoid arthritis. J Rheumatol. 2010;37(10): 2006-2013. CrossRef PubMed

25. Hong YS, Moon SJ, Joo YB, et al. Measurement of interleukin-33 (IL-33) and IL-33 receptors (sST2 and ST2L) in patients with rheumatoid arthritis. J Korean Med Sci. 2011;26(9): 1132-1139. CrossRef PubMed

26. Borsky P, Fiala Z, Andrys C, et al. Alarmins HMGB1, IL-33, S100A7, and S100A12 in psoriasis vulgaris. Mediators Inflamm. 2020;2020:8465083. CrossRef PubMed

27. Minaga K, Watanabe T, Hara A, et al. Identification of serum IFN- $\alpha$ and IL-33 as novel biomarkers for type 1 autoimmune pancreatitis and IgG4-related disease. Sci Rep. 2020;10(1):14879. CrossRef PubMed

28. Bakr RM, Sayed DS, Abd-Elkader AS, Kamel AA, Badran AY. Does interleukin-33 level correlate with the activity of pemphigus vulgaris?: A case-control study. Dermatol Ther. 2021;34(1): e14605. CrossRef PubMed

29. Chatrabnous N, Jafarzadeh A, Ghaderi A, et al. Association of elevated interleukin-33 serum levels with tumor stages in patients with prostate cancer. Eur Cytokine Netw. 2019;30(4): 144-150. PubMed

30. Sun P, Ben Q, Tu S, Dong W, Qi X, Wu Y. Serum interleukin-33 levels in patients with gastric cancer. Dig Dis Sci. 2011;56 (12):3596-3601. CrossRef PubMed

31. Zeng $X$, Zhang $Z$, Gao QQ, et al. Clinical significance of serum interleukin-31 and interleukin-33 levels in patients of endometrial cancer: a case control study. Dis Markers. 2016;2016: 9262919. CrossRef PubMed

32. Hu LA, Fu Y, Zhang DN, Zhang J. Serum IL-33 as a diagnostic and prognostic marker in non-small cell lung cancer. Asian Pac J Cancer Prev. 2013;14(4):2563-2566. CrossRef PubMed

33. Yang ZP, Ling DY, Xie YH, et al. The association of serum IL-33 and SST2 with breast cancer. Dis Markers. 2015;2015:516895. CrossRef PubMed

34. Çekmez F, Fidanci MK, Ayar G, et al. Diagnostic value of Upar, IL-33, and ST2 levels in childhood sepsis. Clin Lab. 2016;62(5): 751-755. CrossRef PubMed

35. Halil H, Tayman C, Buyuktiryaki M, Okur N, Cakır U, Serkant $U$. Serum interleukin-33 as a biomarker in predicting neonatal sepsis in premature infants. Comb Chem High Throughput Screen. 2018;21(7):510-515. CrossRef PubMed

36. Bahrami Mahneh S, Movahedi M, Aryan Z, et al; Universal Scientific Education and Research Network (USERN). Serum IL-33 is elevated in children with asthma and is associated with disease severity. Int Arch Allergy Immunol. 2015;168(3):193-196. CrossRef PubMed

37. Halát G, Haider T, Dedeyan M, Heinz T, Hajdu S, Negrin LL. IL33 and its increased serum levels as an alarmin for imminent pulmonary complications in polytraumatized patients. World J Emerg Surg. 2019;14(1):36. CrossRef PubMed

38. Sundnes O, Ottestad W, Schjalm C, et al. Rapid systemic surge of IL-33 after severe human trauma: a prospective observational study. Mol Med. 2021;27(1):29. CrossRef PubMed

39. Kozłowska E, Brzezińska-Błaszczyk E, Agier J, Wysokiński A, Żelechowska P. Alarmins (IL-33, sST2, HMGB1, and S100B) as potential biomarkers for schizophrenia. J Psychiatr Res. 2021; 138:380-387. CrossRef PubMed

40. Yuan $W$, Mei $X$, Zhang $Y Y$, et al. High expression of interleukin-33/ST2 predicts the progression and poor prognosis in chronic hepatitis B patients with hepatic flare. Am J Med Sci. 2020;360(6):656-661. CrossRef PubMed

41. Venkataraman A, Kumar NP, Hanna LE, et al. Plasma biomarker profiling of PIMS-TS, COVID-19 and SARS-CoV2 seropositive children-a cross-sectional observational study from southern India. EBioMedicine. 2021;66:103317. CrossRef PubMed

42. Duan L, Huang Y, Su Q, et al. Potential of IL-33 for preventing the kidney injury via regulating the lipid metabolism in gout patients. J Diabetes Res. 2016;2016:1028401. CrossRef PubMed

43. Jiao M, Li X, Chen L, et al. Neuroprotective effect of astrocytederived IL-33 in neonatal hypoxic-ischemic brain injury. J Neuroinflammation. 2020;17(1):251. CrossRef PubMed

44. Liu X, Hu R, Pei L, et al. Regulatory T cell is critical for interleukin-33-mediated neuroprotection against stroke. Exp Neurol. 2020;328:113233. CrossRef PubMed

45. Chen Z, Hu Q, Huo Y, Zhang R, Fu Q, Qin X. Serum interleukin-33 is a novel predictive biomarker of hemorrhage transformation and outcome in acute ischemic stroke. J Stroke Cerebrovasc Dis. 2021;30(2):105506. CrossRef PubMed

46. Chen Z, Zhang R, Wu Y, Fu Q, Qin X. Serum interleukin-33 is a predictor of depression in patients with acute ischemic stroke. Curr Neurovasc Res. 2020;17(5):719-724. CrossRef PubMed

47. Li XM, Wang XY, Feng XW, et al. Serum interleukin-33 as a novel marker for long-term prognosis and recurrence in acute ischemic stroke patients. Brain Behav. 2019;9(9):e01369. CrossRef PubMed

48. Miao Y, Zhang ZX, Feng X, Sun WM. IL-33 as a novel serum prognostic marker of intracerebral hemorrhage. Oxid Med Cell Longev. 2021;2021:5597790. CrossRef PubMed

49. Segiet OA, Romuk E, Nowalany-Kozielska E, Wojciechowska C, Piecuch A, Wojnicz R. The concentration of interleukin-33 in heart failure with reduced ejection fraction. Anatol J Cardiol. 2019;21(6):305-313. CrossRef PubMed

50. Koca SS, Kara M, Deniz F, et al. Serum IL-33 level and IL-33 gene polymorphisms in Behçet's disease. Rheumatol Int. 2015;35(3):471-477. CrossRef PubMed

51. Ginaldi L, De Martinis M, Saitta S, et al. Interleukin-33 serum levels in postmenopausal women with osteoporosis. Sci Rep. 2019;9(1):3786. CrossRef PubMed

52. Lin $\mathrm{CY}$, Pfluger $\mathrm{CM}$, Henderson RD, McCombe PA. Reduced levels of interleukin 33 and increased levels of soluble ST2 in subjects with amyotrophic lateral sclerosis. J Neuroimmunol. 2012;249(1-2):93-95. CrossRef PubMed

53. Hasan A, Al-Ghimlas F, Warsame S, et al. IL-33 is negatively associated with the BMI and confers a protective lipid/metabolic profile in non-diabetic but not diabetic subjects. BMC Immunol. 2014;15(1):19. CrossRef PubMed

54. Firouzabadi N, Dashti M, Dehshahri A, Bahramali E. Biomarkers of IL-33 and SST2 and lack of association with carvedilol therapy in heart failure. Clin Pharmacol. 2020;12:53-58. CrossRef PubMed

55. Demyanets S, SpeidI WS, Tentzeris I, et al. Soluble ST2 and interleukin-33 levels in coronary artery disease: relation to disease activity and adverse outcome. PLoS One. 2014;9(4):e95055. CrossRef PubMed

56. Dhillon OS, Narayan HK, Quinn PA, Squire IB, Davies JE, Ng LL. Interleukin 33 and ST2 in non-ST-elevation myocardial infarction: comparison with Global Registry of Acute Coronary Events Risk Scoring and NT-proBNP. Am Heart J. 2011;161(6):1163-1170. CrossRef PubMed 